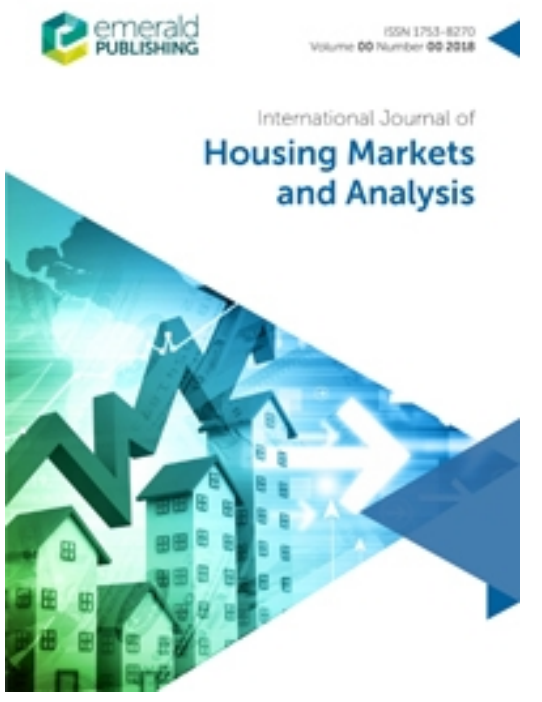

\title{
Relationships between Young Adults' Housing Tenure, Elements of Perceived Job Security and Social Capital in Britain
}

\begin{tabular}{|r|l|}
\hline Journal: & International Journal of Housing Markets and Analysis \\
\hline Manuscript ID & IJHMA-03-2020-0026.R1 \\
\hline Manuscript Type: & Research Paper \\
\hline Keywords: & $\begin{array}{l}\text { Housing Tenure, Social Capital Formation, Job Insecurity, Neighbourhood } \\
\text { Integration, UK, BHPS }\end{array}$ \\
\hline
\end{tabular}

\section{SCHOLARONE ${ }^{m}$ \\ Manuscripts}




\title{
Relationships between Young Adults' Housing Tenure, Elements of Perceived Job Security and Social Capital in Britain
}

\begin{abstract}
Against the backdrop of the changing trends in tenure in the UK housing system, young adults are faced with different situations that continue to shape their housing consumption and decisions. This paper investigates the relationships between young adults' housing tenure, social capital, and elements of perceived job security in Britain. Socio-psychological dimension of housing tenure decisions has been receiving attention by housing market analysts and practitioners seeking deeper understandings of UK housing market dynamics, particularly in the wake of changing tastes and preferences of young people concerning housing decisions across major cities of the world. More specifically, very little research has been done to investigate the contributions of social capital formation, for example, neighbourhood or social integration and social relations, and elements of perceived job security, on housing tenure transitions among British young adults.

A quantitative approach has been applied to the British Household Panel Survey (BHPS) from 2001-2015. We discover that British young adults' homeownership decisions are increasingly influenced by social capital and elements of perceived job insecurity, depending on their tenure of origin. Although we find minimal evidence of a combination effect from our variables of interest. Nevertheless, it is our view that findings from this study will significantly enhance our understanding of tenure shifts amongst young adults in the UK and provide property developers, local authorities, and central governments the knowledge and information to guide economic policies, urban renewal towards achieving better social cohesion and sustainable communities.
\end{abstract}

\section{Introduction}

Housing has continued to be a top subject among policymakers around the world. In the UK, the ongoing housing crisis remains relevant and policymakers are seeking more understanding of how the housing market works to propose better solutions. Among several housing issues, housing tenure decisions (i.e. decisions to buy or rent) have been key to understanding the market demand drivers. After a long steady rise in the owner-occupation sector since the $80 \mathrm{~s}$, the UK private rented sector began to expand in the noughties at the expense of a shrinking owner-occupation sector (Belfield et al., 2015). Considering the importance of housing as a major decision for any individual or household in their lifetime, the influences of housing tenure 
decisions form an integral part of understanding the major shifts in the housing market. In literature, well-established drivers of tenure transitions have been integral to explaining tenure decisions (See (Andrew and Meen, 2003; Di Salvo and Ermisch, 1997). Literature has attributed these trends mainly to demographic, economic, and affordability conditions. Nevertheless, additional explanations of tenure shifts, through socio-psychological contexts, have emerged in literature in recent times (See Aguda, 2019; Ben-Shahar, 2007; Drew, 2014 and Reid, 2013). More recently, there has been a record rise in employment in the UK, but the record has often come with criticisms of questionable employment and working conditions. This inadvertently affects an individual's perception of job security and consequently an important decision for their social life. To date, no housing tenure research has explored the impact of individual perception of job security and the possible linkage with social connections to contribute to housing tenure decisions.

To explore these possible additional influences, the paper is formed of five main sections. The next section provides background and review of the drivers of tenure transitions. Within this review, the conceptual framework and justification of social capital linkages and elements of perceived job security are achieved. Afterwards, the research questions, applicable data and methodology are discussed and justified in section 3. The established drivers of tenure choice are controlled for in fixed-effects logistic regression models that include social capital and perceived job security variables. Following this is a discussion of results and conclusions are carried out in sections 4 and 5 respectively.

\section{Background}

\subsection{Established drivers of housing tenure transitions in Britain}

It is no question as to how affordability is considered as a major housing issue in the UK and major cities around the world. This is also very much present in previous housing-related studies. In the UK, housing affordability has worsened over time, mostly affecting young adults. Some prominent factors are income and wealth disparity among generations (Andrew and Meen, 2003) coupled with dependence on the bank of mum and dad (Alakeson, 2011; Scanlon et al, 2017), income risks (Gathergood, 2011), borrowing restrictions (Andrew and Pannell, 2006; Andrew, 2012) and user cost of owning to renting (Bourassa, 1995; Ermisch and Di Salvo, 1996). Although, these are mostly external microeconomic factors to individuals and 
households. Nevertheless, they depict a picture of changes in the overall economy and the effect of the changes in the housing sector ${ }^{1}$.

Drivers of tenure transitions also exist along demographic lines, such as household composition, race, sex, age and mobility patterns (Baddeley, 2011; Drew, 2014; Fu, 2014). These also include influences of pathways and mobility patterns for young people's tenure described in Ford et al. (2012); Heath (2008) and Clapham et al. (2014). Homeownership remains the largest and most popular tenure. Nevertheless, considering the recent housing mobility and tenure shifts, the private rented sector may gradually be becoming a more stable tenure rather than a temporary tenure as was suggested in Kemp (2002) and Ford et al (2002). Essentially, young people's decisions on housing tenure have continued to change, by drifting towards private renting (Heath, 2008). Economic and demographic factors have proven to be core to explaining tenure decisions, but are yet to fully explain the shifts. Hence, there is a need to further understand these changing patterns in the housing market.

Socio-psychological dimensions have provided additional explanations in recent literature. However, they are yet to be well developed in an empirical context. Theoretically, social dimensions exist in housing tenure studies in the form of socialisation processes unfolding over time through parental influence or the immediate environment. More specifically, socialisation towards homeownership, for instance, deals broadly with developing aspirations and preferences (Ben-Shahar, 2007); inspirations (Reid, 2013); habitual behaviours (Ab Majid et al., 2014); path-dependence (Lersch and Luijkx, 2015; Coulter, 2016; Lux et al., 2018; Aguda, 2019). The psychology literature further involves the possibility of developing values, prospects and norms (Drew, 2014) and other factors such as privacy, comfort, cautiousness, safety, welfare, class etc. (Fu, 2014) towards housing tenure choice. Homeownership is regarded in the psychology literature as the utmost tenure, but this may be changing among young people. This is because young people are beginning to question homeownership as a prerequisite for security and satisfying life (Baum, 2017). Nevertheless, a significant number of this group still believe that homeownership must be achieved either directly from parental housing or through the private rented sector pathway (Clapham et al, 2014). For this, parental financial assistance

\footnotetext{
${ }^{1}$ See Jones (2016) for a detailed summary of the economic issues affecting the UK housing sector before and after the global financial crisis.
}

Page | 3 
has been found to rise with time, while other shreds of evidence show longer stay in parental housing over time (Tatch, 2007)2.

\subsection{Additional drivers - social capital and perceived job insecurity in housing tenure transitions}

Recent tenure shifts appear to continue to defy the understanding of the key drivers of housing tenure transitions in Britain. As the private rented sector continues to expand while the owneroccupation sector shrinks, questions have been raised whether young adults, the most affected age group, are beginning to settle for the status quo. This is linked to the possibility of following others' decisions, norms and advice as illustrated in Aguda (2019). The suggestion is also strongly based on the contributions of social capital - part of the socio-psychology framework. More specifically, social capital deals with associations that form common standards and beliefs, thereby enabling collaborations and support within or among groups (Cote and Healy, 2001). Concerning housing tenure decisions, it could result from bonds formed through integration in an area and with family or links formed with individuals within local organisations they identify with (Aguda, 2019). However, social capital effects may not be independent of the current economic conditions affecting young people's important decision. Eventual outcomes may partly result from advice obtained from associations formed within social capital linkages with the current economic conditions; or other forms of linkages between social capital and the labour market as illustrated in Brook (2005). Such relationships may, directly or indirectly, shape individual outcomes. Evidence of such occurrences exists in recent qualitative studies. For instance, Clapham et al (2014, pp 2022) observed that young individuals relate with their neighbours regarding their current economic and housing situations, with the tendency of reacting to other's expectations.

On the one hand, employment rates have improved in the Labour market (Office of National Statistics, 2019), but this is also met with some evidence of corresponding job insecurity. How individuals perceive their current jobs is important for making big decisions such as housing. Gallie et al (2017) found that actual job insecurity has worsened over time due to poor working conditions, unfavourable job status, economic status etc., thereby negatively impacting on an individual's eventual social outcomes. These claims, however, conflicts with Felstead et al (2017)'s findings as they found otherwise. Nevertheless, the conflict in findings appears to be

\footnotetext{
${ }^{2}$ This also stems from psychological beliefs and the socialisation hypothesis.
} 
drawn along the lines of objectivity and subjectivity (Erlinghagen, 2007; Gallie et al, 2017). Perception of job insecurity, although subjective and psychological, is very likely a result of the actual working conditions and the macroeconomy (Erlinghagen, 2007). The assumption is that such perceptions form part of discussions and advice obtained from social capital linkages, thereby contributing to tenure transitions in Britain. It is expected that the perception of job insecurity would negatively correlate with, say, homeownership transition. Hence, it becomes necessary to empirically investigate the extent to which the perception of job insecurity influence housing tenure decisions. Furthermore, exploring the relationships between these perceptions and social capital linkages for housing tenure transitions could provide additional understanding to the tenure shifts in Britain.

\section{The research question, data and method}

Some questions have emerged from our literature review that would be worth stating thus:

- Are social capital linkages gradually becoming a stabilized driver of housing tenure transitions in Britain?

- What impact does "perceived job insecurity" has on housing tenure shifts and what are the implications for young households in Britain?

- Is there a connection between "perceived job insecurity" and social capital in contributing to housing tenure shifts in Britain?

To determine the answers to these questions through an empirical approach, we make use of the harmonised British Household Panel Survey (BHPS) data (University of Essex, Institute for Social and Economic Research, 2019). The BHPS, which is an annual collection of data relating to socio-economic situations of UK individuals and households, is popular for housing tenure studies across the UK. It started in 1991 (wave 1) with about 5500 households and 10,300 individuals and continues to date. However, the rage of data applicable in this study is from wave 11 (i.e. the year 2001) to wave 25 (i.e. year 2014/2015). The choice of the period is for two reasons. Firstly, the period considered corresponds with the time when the private rented sector started expanding while at the same time, the owner-occupation sector declining ${ }^{3}$. Secondly, specific BHPS data representing proxies for social capital were collected from the year 2000 onward.

\footnotetext{
${ }^{3}$ See Pattison (2010)
}

Page | 5 
Proxies representing social capital in the BHPS are adopted from Aguda (2019). These provide information on the tendency of becoming integrated into an area through bonds formed with neighbours or neighbourhoods (Leviten-Reid and Matthew (2017); identification with meaningful socio-economic groups and networks (Lin, 2017; Brady, 2015); and relationships formed with family or friends (Brook, 2005; Brady, 2015). These variables are further explained, with the questions and interpretations in table 1. Furthermore, the BHPS provides measures of perception of job insecurity, such as their likelihood of becoming unemployed in the following year - "eprosc" (Green et al, 2001; Fevre, 2007) or their levels of satisfaction with their job security - "jbsat4" (Jara, 2015). However, due to the limited collection of "eprosc"4, make use of the more consistent variable "jbsat4". We also make use of data relating to job status - "jbstat" to create a measure that reveals the acquisition of a new job ${ }^{5}$. This is because job status tends to influence the perception of job insecurity (Erlinghagen, 2007). Levels of perceived job security provide us with information on the possibilities of measuring the level of assurance for economic stability and sustainability, which helps in important decision-making.

\section{Table 1 about here}

The analysis focuses on young adults aged $18-34$ (at first appearance). The choice of age range is because they are mostly affected by the recent tenure shifts (Ministry of Housing, Communities and Local Government, 2018). Furthermore, it concentrates on homeownership transitions from either private renting ${ }^{6}$ or parental housing only. Social renting falls outside the scope of this study as the social rented sector size has been declining since the 80's mainly due to policy drive (Malpass and Victory, 2010). Parental housing stayers have been considered separately due to their non-independent status (Andrew, 2012). Additionally, recent studies have shown evidence of young people staying longer in parental housing to either jump or pass through the private rented sector on their path to homeownership (Clapham et al, 2014). To ensure that a longitudinal dataset is maintained, respondents who participated in, at least, three

\footnotetext{
4 "Eprosc" was collected only in waves 6 and 7 of the BHPS

${ }^{5}$ This reveals whether they have recently acquired a new job or moved into full time employment. Alternative approach is to include the year they got their first job, but this may be misleading as it does not capture whether they have been in and out of work.

${ }^{6}$ Those in private renting are independent heads of households or their partners.
} 
consecutive waves were retained (Aguda, 2019) ${ }^{7}$. The sample data resulted in 31,126 observations and 5479 individuals who are yet to become a homeowner at their first survey participation (appendix A). The mean age is 25 years at first participation with female amounting to 52 percent of the sample.

The model applicable for our analysis is the fixed effects ${ }^{8}$ logistic regression of homeownership transition, using the Stata software and the command clogit (StataCorp, 2019). This predicts the probability of making a transition to homeownership from either private renting or parental housing, conditional on unobservable fixed effects for each individual. The model is further applied depending on the tenure of origin. Hence, we have two separate models of the same computation (equation 1), where model 1 considers individuals making the transition from Private Renting (PR) whereas model 2 considers transitions from Parental Housing $(\mathrm{PH})$ to Homeownership (HO). Alongside the variables of interest, our models control for the established drivers of tenure transitions and the wave dummies - not reported for brevity. For the first steps, the independent variables of interest are tested in the models of homeownership transition. Afterwards, the possible interactions between social capital and levels of perceived job security are explored in the models.

$P\left(y_{i t}=1 \mid X_{i t}\right)=f\left(\alpha_{i}+X_{i t} \beta+Z_{i t} \delta\right)$

Equation 1 displays the fixed-effects logit where $\mathrm{P}$ is the probability of an individual $(i)$ becoming a homeowner $(\mathrm{y})$ in a particular year $(t)$, conditional on the applicable variables of interest $\mathrm{X}$. The left-hand side equates to the function of each individual's unobservable effects represented by $\alpha_{i}$; the variables of interest from table 1 represented by $X_{i t}$; and the control (established) variables represented by $Z_{i t}$. Lastly, $\beta$ and $\delta$ represent the coefficients.

\section{Discussion of results}

The results are displayed as odds ratio, z-values and average marginal effects ${ }^{9}$ of homeownership transition. Both models (1 and 2 ) are statistically significant and they are displayed across three tables. Appendix B displays the results from the established drivers of

\footnotetext{
${ }^{7}$ The unbalanced panel data suggests that the number of observations will not be consistent with individuals times waves of the survey.

${ }^{8}$ Fixed-effects approach, rather than random-effects, takes care of unobserved heterogeneity (Gormley and Matsa, 2013) and guides against bias due to reverse causality (Leszczensky and Wolbring, 2018).

${ }^{9}$ In this study, average marginal effects are only applicable to the non-interaction terms, as it is not possible to estimate the marginal effects for the interaction terms using Stata.
} 
tenure transitions in our models. Table 2 displays the results from the variables of interest without the interaction between social capital and levels of perceived job security. Lastly, Table 3 displays the results from the interaction terms. From the established drivers of tenure transition, economic factors ${ }^{10}$ are first considered before other factors. Here, we control for respondents' wage rate, lower quartile Local Authority District (LAD) house prices ${ }^{11}$ and net rent. Unsurprisingly, the wage rate shows a positive correlation with homeownership transition. It is significant with about 1 odd with a unit increase in wage rate for both private renters and parental housing stayers to make the same type of transition. The house prices are converted to four quintiles (representing house price levels), with the lowest quintile as the reference point. We expect that young individuals would normally negotiate in the lower end of the property market. The higher quintiles are negatively correlated with homeownership transition but mostly insignificant. A unit increase in the net rent per thousand for private renters increases their chances of $\mathrm{HO}$ transition by about 1.5 odds. This suggests that the effect of net rent on homeownership could be either positive or negative, depending on the group concerned. For young private renters, they are likely to consider homeownership as rents increase or they may become stuck in the sector. PH stayers, on the other hand, are likely to hold off longer or get assistance.

\section{Table 2 about here}

Demographic factors are equally important in tenure transition studies. In our models, we control for the age groups, sex ${ }^{12}$, race ${ }^{13}$ and household composition. Age 16-24 is made the reference point in our models. As the age group increase, the chances of private renters becoming homeowners increase by about 2.5 and 2.9 odds for individuals aged 25-29 and 30-34 respectively. Age group appears to be insignificant for $\mathrm{PH}$ stayers looking to switch directly to HO. Furthermore, independent individuals may be better exposed to the labour market and displaying more readiness for $\mathrm{HO}$ transition than non-independent individuals as they grow older. For household composition, we include the number of children in the household and the

\footnotetext{
${ }^{10}$ Additional economic factors can be explored based on data availability, but are already covered in other literature, such as household savings (Haurin et al, 1996), student loans (Andrew, 2010) and mortgage availability (Andrews, 2012).

${ }^{11}$ Lower quartile LAD house prices are expected to reasonably reflect affordability and geographical search area for young adults or first-time buyers (Cribb and Simpson, 2018).

${ }^{12}$ Sex was automatically omitted in our (fixed-effects) regression due to no change in the variable for each individual throughout the survey period.

${ }^{13}$ The same applicable as above note.
} 
presence of partner. More child in the household means more financial commitments, whereas additional adult in the household will boost the financial resource required for homeownership transition. This is further reflected in the results obtained.

Social capital and levels of perceived job security are the main focus of our investigation of homeownership transitions for young adults between the year 2000 and 2014/15. The first set of variables of interest related to indications of integration in the area where they live, which tends to prolong their stay in their current area and tenure (Table 2). Private renters who indicated that they liked their neighbourhood are less likely to switch to HO by about 7 percent (at 95 percent confidence interval). Furthermore, private renters who interact with their neighbours more often are less likely (by 0.5 odds) to switch to $\mathrm{HO}$. It is interesting to discover that the neighbourhood integration measures, and other social capital drivers, are less significant for $\mathrm{PH}$ stayers looking to switch to $\mathrm{HO}$, suggesting that they are equally likely to make the transition as others. The social capital drivers may be more influential to private renters, in comparison to $\mathrm{PH}$ stayers, due to their independent and more settled status.

The second set of variables is the proxies indicating bonds formed with family or links formed with individuals within socio-economic groups or local organisations they identify with. These tend to open up trusts, patterns, norms, standards, beliefs, expectations or assistance within the social connections. Private renters who are active in one or more local organisation possess the tendency of switching to $\mathrm{HO}$ by about 5.7 percent marginally (at 95 percent confidence interval). As PR is often considered a step towards HO for many households (Kemp, 2002), having the extra social influence may further help in such important decision-making. This is also similar to the frequency of contact with parents ${ }^{14}$. Having the least contact with parent(s) is made the reference point. Individuals who have the closest relationship with their parent(s) have higher chances of $\mathrm{HO}$ transition by about 11.5 percent. By keeping up with parents, the chances of receiving assistance for homeownership transition are higher.

Our proxies representing levels of perception of job security and the acquisition of a new job reveal traces of concern individuals have over present employment and economic conditions, which consequently drive important decision-making and social outcomes. Low perception of job security is the reference point in our models. Private renters with a high perception of job

\footnotetext{
${ }^{14}$ In order to avoid bias, the predictor is omitted in model 2 as it is expected that PH stayers are likely to have very close contact with parents.
}

Page | 9 
security are more likely to switch to $\mathrm{HO}$ by 7.5 percent marginally (and at 95 percent confidence interval). However, this is not the case with $\mathrm{PH}$ stayers, as they are driven by job acquisition, rather than the levels of perception of job security, in determining the possibility of a direct $\mathrm{HO}$ switch. The result provides evidence that the perception of job insecurity drives young adults in different ways depending on their original tenure. For private renters, low perception of job security appears to delay their HO transition, as they will be worried about the sustainability of such a move. On the other hand, PH stayers appear more concerned about acquiring a new job to boost their perception of job security or continue to delay direct $\mathrm{HO}$ switch. Whether this is further connected to the relationships formed within social groups remains a question to resolve.

Lastly, we explore the relationships between the levels of perception of job security and main social capital drivers (table 3 ). The explanation surrounding this puts forward the possibility of being influenced by a combination of subjective nature of job security and discussions and advice obtained through social capital linkages. From the results obtained, the possibilities of a suggested combination effect between social capital and perception of job insecurity are minimal, as they are equally likely to switch to $\mathrm{HO}$ for most of the combinations explored. Only $\mathrm{PH}$ stayers who liked where they lived and with a high perception of job security are more likely to switch directly to $\mathrm{HO}$ by about 2.3 odds (at 95 percent confidence interval). This is the case, provided all other $\mathrm{PH}$ stayers liked their neighbourhoods but perceive a low job security. It affirms the importance of an individual's perception of their job security in contributing to HO transition. More specifically, it reveals the extent to which perception of job security, a reflection of actual working conditions and the economy, may influence an individual's eventual outcomes such as housing tenure decisions.

Table 3 about here

\section{Conclusions}

In this study, we investigate the influence of social capital and perceptions of job insecurity on housing tenure and especially homeownership transitions. The investigation builds on the growing literature on socio-psychological drivers of housing tenure transitions, by exploring possible additional factors empirically. It further tests the possible combinations of the variables of interest as factors contributing to housing tenure decisions. The findings are unique to the age group and survey period.

Page | 10 
We control for established drivers in our models, alongside dummies representing each wave. However, more importantly, the variables of interest further provide additional explanations in ways that have not been considered in previous studies. Neighbourhood integration contributes well to $\mathrm{HO}$ delays, especially for private renters. Redistribution of tenure through this effect could be seen as a growing trend, as $\mathrm{HO}$ may now be either questioned as a form of security and satisfying life (Baum, 2017); or seen differently by the younger generation who are beginning to prefer flexibility (Pattison, 2010). Hence, young adults who are settled in their neighbourhoods may now see living in the private rented sector for much longer as the new norm, rather than as temporary tenure. On the positive side, it further suggests a lesser feeling of being disadvantaged if they find themselves in mixed neighbourhoods. It is, therefore, a form of awareness to the stakeholders in the built environment on the importance of continuous improvement on tenure mix for better social cohesion and sustainable communities.

We could also observe elements of trust and exposure to useful resources possibly at play among young private renters who have (strong or weak) ties with families or local organization. This tends to put them at an advantage over others in the same socio-economic group and housing sector. Whether the same is peculiar to $\mathrm{PH}$ stayers could not be ascertained, as the proxy representing parental intimacy was omitted from the tenure pathway to avoid bias. Nevertheless, it is interesting that the social capital drivers are not very important for $\mathrm{PH}$ stayers, as direct $\mathrm{HO}$ switch appears to be a much bigger move than from $\mathrm{PR}^{15}$. $\mathrm{PH}$ stayers were however seen to hold on until they acquire a new job before making a big move to $\mathrm{HO}$, suggesting that a boost in their perception of job security, through job acquisition, is an observable psychological factor. We can also conclude that the subjective nature of perceptions of job security (i.e. sustainable job or securing a new position) looks to apply differently to young adults based on their tenure of origin.

Although we find minimal effects from the combinations of social capital and perceived job security drivers. Nevertheless, the specific measures of interest provide us with additional knowledge on the drivers of homeownership transitions for British young adults. On the one hand, the findings shed more light on the present economic situation leading to the perception of their job security for young adults, which tends to influence their social life and housing decisions. On the other hand, property developers, local authorities, and central governments

\footnotetext{
${ }^{15} \mathrm{PH}$ stayers need to move from a non-independent tenure to HO, unlike moving from PR, hence the bigger move.
} 
will have more knowledge and information to guide urban renewal towards achieving better social cohesion and sustainable communities. 


\section{References}

Ab Majid, R., Said, R. \& Daud, M.N. (2014). “The assessment of young couples' behaviour on expenditure towards homeownership", Research Journal, Vol. 35.

Aguda, O. (2019). Contributions of path-dependency and social capital drivers to housing tenure transitions in Britain. International Journal of Housing Markets and Analysis.

Alakeson, V. (2011). Making a Rented House a Home: Housing solutions for 'generation rent'. Resolution Foundation.

Allison, P.D. (2009). Fixed effects regression models (Vol. 160). SAGE publications.

Andrew, M. (2010). The changing route to owner occupation: The impact of student debt. Housing Studies, 25(1), pp.39-62.

Andrew, M. (2012). The changing route to owner-occupation: the impact of borrowing constraints on young adult homeownership transitions in Britain in the 1990s. Urban Studies, 49(8), pp.1659-1678.

Andrew, M. \& Meen, G. (2003). "Housing transactions and the changing decisions of young households in Britain: the microeconomic evidence", Real Estate Economics, Vol. 31 No. 1, pp. 117-138.

Andrew, M. \& Pannell, B. (2006). Housing tenure choices by the young. Housing Finance, 7, 113.

Baddeley, M. (2011). Social Influence and Household Decision-Making: A Behavioural Analysis of Housing Demand.

Baum, A. (2017). PropTech 3.0: the future of real estate.

Belfield, C., Chandler, D. and Joyce, R., 2015. Housing: trends in prices, costs and tenure. Institute for Fiscal Studies.

Ben-Shahar, D. (2007). "Tenure choice in the housing market psychological versus economic factors", Environment and Behavior, Vol. 39 No. 6, pp. 841-858. 
Bourassa, S. C. (1995). A model of housing tenure choice in Australia. Journal of Urban Economics, 37, 161-175.

Brook, K. (2005), “Labour market participation: the influence of social capital”, Labour Market Trends, Vol. 3 No. 1, pp. 113-123.

Clapham, D., Mackie, P., Orford, S., Thomas, I. \& Buckley, K. (2014). "The housing pathways of young people in the UK", Environment and Planning A, Vol. 46 No. 8, pp. 2016-2031.

Côté, S. \& Healy, T. (2001). The well-being of nations: The role of human and social capital. Paris: Organisation for Economic Co-operation and Development.

Coulter, R. (2016). "Parental background and housing outcomes in young adulthood", Housing Studies, Vol. 33 No. 2, pp. 1-23.

Cribb, J. and Simpson, P. (2018). Barriers to homeownership for young adults. IFS Green Budget: October.

Di Salvo, P. \& Ermisch, J. (1997). "Analysis of the dynamics of housing tenure choice in Britain", Journal of Urban Economics, Vol. 42 No. 1, pp. 1-17.

Drew, R.B. (2014). Believing in Homeownership: Behavioral Drivers of Housing Tenure Decisions, Joint Center for Housing Studies, Cambridge.

Erlinghagen, M. (2007). Self-perceived job insecurity and social context: A multi-level analysis of 17 European countries. European Sociological Review, 24(2), pp.183-197.

Ermisch, J. \& Di Salvo, P. (1996). Surprises and housing tenure decisions in Great Britain. Journal of Housing Economics, 5, 247-273.

Felstead, A., Gallie, D., Green, F. \& Henseke, G. (2017). Insecurity at Work in Britain: First Findings from the Skills and Employment Survey 2017, available at: https://www.cardiff.ac.uk/ data/assets/pdf file/0011/1309457/6 Insecurity Minireport Final.pdf

(Accessed 3 August 2019).

Fevre, R. (2007). Employment insecurity and social theory: the power of nightmares. Work, employment and society, 21(3), pp.517-535. 
Ford, J., Rugg, J. \& Burrows, R. (2002). "Conceptualising the contemporary role of housing in the transition to adult life in England", Urban Studies, Vol. 39 No. 13, pp. 2455-2467.

Fu, K. (2014). A review on housing tenure choice. In Proceedings of the 17th international symposium on advancement of construction management and real estate (pp. 351-360). Springer, Berlin, Heidelberg.

Gallie, D., Felstead, A., Green, F. \& Inanc, H. (2017). The hidden face of job insecurity. Work, employment and society, 31(1), pp.36-53.

Gathergood, J. (2011). "Unemployment risk, house price risk and the transition into homeownership in the United Kingdom", Journal of Housing Economics, Vol. 20 No. 3, pp. 200209.

Gormley, T.A. \& Matsa, D.A. (2013). Common errors: How to (and not to) control for unobserved heterogeneity. The Review of Financial Studies, 27(2), pp.617-661.

Green, F., Dickerson, A., Carruth, A. \& Campbell, D. (2001). An analysis of subjective views of job insecurity (No. 01, 08). Department of Economics Discussion Paper.

Haurin, D.R., Hendershott, P.H. and Wachter, S.M. (1996). Borrowing constraints and the tenure choice of young households (No. w5630). National bureau of economic research.

Heath, S. (2008). Housing Choices and Issues for Young People in the UK, Joseph Rowntree Foundation, York.

Kemp, P. (2002), Private Renting in Transition, Chartered Institute of Housing, Coventry.

Lersch, P.M. \& Luijkx, R. (2015), "Intergenerational transmission of homeownership in Europe: revisiting the socialisation hypothesis", Social Science Research, Vol. 49, pp. 327-342.

Leszczensky, L. \& Wolbring, T. (2018). How to deal with reverse causality using panel data? Recommendations for researchers based on a simulation study.

Lux, M., Samec, T., Bartos, V., Sunega, P., Palguta, J., Boumová, I. \& Kážmér, L. (2018). "Who actually decides? Parental influence on the housing tenure choice of their children", Urban Studies, Vol. 55 No. 2, pp. 406-426. 
Malpass, P. \& Victory, C. (2010). The modernisation of social housing in England. International Journal of Housing Policy, 10(1), pp.3-18.

Ministry of Housing, Communities and Local Government. (2018). English Housing Survey Headline Report 2016-17, available at: https://assets.publishing.service.gov.uk/government/uploads/system/uploads/attachment data/file/70 5821/2016-17 EHS Headline Report.pdf (Accessed 3 August 2019).

Office for National Statistics. (2013). Labour market overview, UK: July 2019, available at: https://www.ons.gov.uk/employmentandlabourmarket/peopleinwork/employmentandemployeety pes/bulletins/uklabourmarket/july2019 (Accessed 3 August 2019).

Pattison, B. (2010). Tenure Trends in the UK Housing System: Will the Private Rented Sector Continue to Grow? BSHF.

Reid, C. (2013). To Buy or Not to Buy? Understanding Tenure Preferences and the DecisionMaking Processes of Lower-Income Households, Joint Center for Housing Studies of Harvard University, Cambridge.

Jara, H. (2015). The effect of job insecurity on labour supply. Australian Journal of Labour Economics, 18(2), p.187.

Scanlon, K., Whitehead, C. and Blanc, F. (2017). The Bank of Mum and Dad.

StataCorp. (2019), "clogit - Conditional (fixed-effects) logistic regression", in Stata Base Reference Manual Release 16, Stata Press, College Station, pp. 251-266, available at: www.stata.com/manuals/r.pdf

Tatch, J. (2007). Affordability—are parents helping. Housing Finance, 3, 1-11.

University of Essex, Institute for Social and Economic Research. (2019). Understanding Society: Waves 1-8, 2009-2017 and Harmonised BHPS: Waves 1-18, 1991-2009. [data collection]. 11th Edition. UK Data Service. SN: 6614, http://doi.org/10.5255/UKDA-SN-6614-12 


\section{Relationships between Young Adults' Housing Tenure, Elements of Perceived Job Security and Social Capital in Britain}

\begin{tabular}{|c|c|c|c|}
\hline $\begin{array}{l}\text { BHPS } \\
\text { Variables }\end{array}$ & Question & Response & Regroup/recode \\
\hline Iknbrd & Do you like living in this neighbourhood? & Yes (1); No (2) & No (0); Yes (1) \\
\hline frna & $\begin{array}{l}\text { How frequently do you interact with any of your } \\
\text { neighbours? }\end{array}$ & $\begin{array}{l}\text { "On most days" (1) - } \\
\text { "Never" (5) }\end{array}$ & $\begin{array}{l}\text { Low (4-5); Moderate } \\
\text { (3); } \\
\text { and High (1-2) }\end{array}$ \\
\hline orga & Are you active in any of the organisations listed? & Yes (1); No (2) & No $(0)$; Yes (1) \\
\hline $\begin{array}{l}\text { masee, pasee, } \\
\text { matel, patel }\end{array}$ & $\begin{array}{l}\text { How frequently are you in contact with parent(s) } \\
\text { (physically or phone call)? }\end{array}$ & $\begin{array}{l}\text { "Daily" (1) - "Never" } \\
\text { (6) }\end{array}$ & $\begin{array}{l}\text { Low (5-6); Moderate (3- } \\
\text { 4); \& High (1-2) }\end{array}$ \\
\hline jbsat4 & Are you satisfied with your job security? & $\begin{array}{l}\text { "Not satisfied at all" } \\
\text { (1) - "Completely } \\
\text { satisfied" (7) }\end{array}$ & $\begin{array}{l}\text { Low satisfaction (1-2); } \\
\text { medium satisfaction (3- } \\
\text { 5); High satisfaction (6- } \\
\text { 7) }\end{array}$ \\
\hline jbstat & $\begin{array}{l}\text { What is your current economic activi } \\
\text { employment status }\end{array}$ & $\begin{array}{l}\text { "self-employed" (1) - } \\
\text { "other" (10) }\end{array}$ & New job (1); other (0) \\
\hline
\end{tabular}

Table 1: Variables of interest taken from the BHPS 
Model 1

Variables of interest

Liked neighbourhood

Interact with neighbours (med) $)_{t-1}$, ref=low

Interact with neighbours (high) $t-1$

Active in any local organisation $t-1$

Contact with parent $(\mathrm{med})^{*}{ }_{t-1}$, ref $=$ low

Contact with parent (high) ${ }_{t-1}$

Perceived job security (med) ${ }_{t-1}$, ref $=$ low

Perceived job security (high) ${ }_{t-1}$

New job

Log-likelihood

LR $\mathrm{chi}^{2}(32)$

Prob $>\mathrm{chi}^{2}$

Observations used or switched to $\mathrm{HO}^{1}$

Number of individuals

${ }^{* * *} p<0.01,{ }^{* *} p<0.05,{ }^{*} p<0.1$

Notes: PR=Private Renting; $\mathrm{PH}=$ Parental Housing; $\mathrm{HO}=$ Home Ownership; $t-1=$ lagged by a year; ${ }^{*}=$ omitted in model 2 as $\mathrm{PH}$ stayers are expected to mostly have close contact to parents.

Table 2: Results from variables of interest without the interaction between social capital and levels of perceived job security

\footnotetext{
${ }^{1}$ Addition of the two observations used may not equate to 31,126 . This is due to observations automatically dropped because they never attained home ownership throughout the survey period (Allison, 2009).
}

Page | 2
PR to OWN transition

(without interactions)

Marginal

$\mathrm{PH}$ to OWN transition

Odds

(without interactions)

ratio

z-values

Marginal

0.887

$-1.82$

$-0.066$

$-2.89$

$-0.085$

$0.749^{*}$

$-1.68$

$-0.051$

$1.509^{* *}$

$2.12 \quad 0.057$

0.88

$2.328^{* * *}$

n.a.

0.645

n.a.

n.a.

$1.823^{*}$

1.88

0.088

0.719

$-0.077$

$-0.058$

1.226

0.89

0.028

$-917.9589$

319.89

0.000

4,052

536 


\section{Variables of interest}

ref $=$ Perceived job security (low) \& liked neighbourhood

Perceived job security (med) \& liked neighbourhood

Perceived job security (high) \& liked neighbourhood

ref $=$ Perceived job security (med) \& Interact with neighbours (low)

Perceived job security (med) \& Interact with neighbours (med)

Perceived job security (med) \& Interact with neighbours (high)

ref $=$ Perceived job security (high) \& Interact with neighbours (low)

Perceived job security (high) \& Interact with neighbours (med)

Perceived job security (high) \& Interact with neighbours (high)

ref $=$ Perceived job security (low) \& Active in a local org.

Perceived job security (med) \& Active in a local org.

Perceived job security (high) \& Active in a local org.

ref $=$ Perceived job security (med) \& Contact with parent (low)

Perceived job security (med) \& Contact with parent (med)

Perceived job security (med) \& Contact with parent (high)

ref $=$ Perceived job security (high) \& Contact with parent (low)

Perceived job security (high) \& Contact with parent (med)

Perceived job security (high) \& Contact with parent (high)

ref= same position \& disliked neighbourhood

New job \& liked neighbourhood

ref $=$ New job \& Interact with neighbours (low)

New job \& Interact with neighbours (med)

New job \& Interact with neighbours (high)

\section{Model 3}

PR to OWN transition

(with interactions)

\section{Odds ratio z-values}

\begin{tabular}{|c|c|c|c|}
\hline 0.672 & -0.37 & 2.049 & 0.74 \\
\hline 1.561 & 0.74 & $2.308^{\star *}$ & 2.05 \\
\hline 0.849 & -0.15 & 3.136 & 1.31 \\
\hline 0.283 & -1.60 & 1.515 & 0.54 \\
\hline 1.367 & 0.49 & 1.061 & 0.15 \\
\hline 0.694 & -0.77 & $0.466^{*}$ & -2.40 \\
\hline 2.711 & 1.45 & 0.941 & -0.11 \\
\hline 1.678 & 1.30 & 1.141 & 0.53 \\
\hline 0.336 & -1.35 & n.a. & n.a. \\
\hline 0.452 & -1.00 & n.a. & n.a. \\
\hline 0.564 & -1.32 & n.a. & n.a. \\
\hline 0.701 & -0.77 & n.a. & n.a. \\
\hline 0.581 & -0.76 & 0.482 & -1.29 \\
\hline 0.389 & -1.15 & 0.801 & -0.3 \\
\hline 0.747 & -0.45 & 1.315 & 0.58 \\
\hline
\end{tabular}

Model 4

$\mathrm{PH}$ to OWN transition

(with interactions)

Odds ratio z-values

0.74

$-0.11$

n.a.

a.

n.a.

a.

0.58 
ref= same position \& no org.

New job \& Active in a local org.

1.001

0.00

0.692

$-1.01$

ref $=$ New job \& Contact with parent (low)

New job \& Contact with parent (med)

1.49

2.136

1.29

n.a.

n.a.

New job \& Contact with parent (high)

\begin{tabular}{lrr}
\hline Log-likelihood & -532.667 & -917.959 \\
LR chi²(32) & 559.13 & 319.89 \\
Prob $>$ chi $^{2}$ & 0.000 & 0.000 \\
Observations used or switched to HO & 3,074 & 4,052 \\
Number of pid & 410 & 536 \\
$* * *$ & &
\end{tabular}

n.a.

n.a.

Notes: $\mathrm{PR}=$ Private Renting; $\mathrm{PH}=$ Parental Housing; $\mathrm{HO}=$ Home Ownership.

Table 3: Results from the interaction term 


\begin{tabular}{|c|c|c|c|c|c|}
\hline Variable & Observations & Mean & Std. dev & Minimum & Maximum \\
\hline \multicolumn{6}{|l|}{ Dependent } \\
\hline $\begin{array}{l}\mathrm{PR} \text { to } \mathrm{HO} \\
\mathrm{PH} \text { to } \mathrm{HO}\end{array}$ & $\begin{array}{l}31,126 \\
31,126\end{array}$ & $\begin{array}{l}0.0138 \\
0.0183\end{array}$ & $\begin{array}{l}0.117 \\
0.134\end{array}$ & $\begin{array}{l}0 \\
0\end{array}$ & $\begin{array}{l}1 \\
1\end{array}$ \\
\hline \multicolumn{6}{|l|}{ Control variables } \\
\hline Wage rate ${ }^{c}$ & 31,126 & 0.8507 & 1.654 & 0 & 61.25 \\
\hline Wage rate $s^{c}$ & 31,126 & 3.4608 & 36.109 & 0 & 3751.56 \\
\hline Female & 31,126 & 0.5384 & 0.499 & 0 & 1 \\
\hline Age $25-29$, ref $=18-24$ & 31,126 & 0.2096 & 0.407 & 0 & 1 \\
\hline Age $30-34$ & 31,126 & 0.5157 & 0.500 & 0 & 1 \\
\hline 1-2 children in household, ref $=$ no child & 31,126 & 0.4388 & 0.496 & 0 & 1 \\
\hline $3+$ children in household & 31,126 & 0.0818 & 0.274 & 0 & 1 \\
\hline Non-white, ref=White & 31,126 & 0.5590 & 0.497 & 0 & 1 \\
\hline Presence of spouse in household & 31,126 & 0.5205 & 0.500 & 0 & 1 \\
\hline Q2 house prices, ref $=Q 1$ & 31,126 & 0.1402 & 0.347 & 0 & 1 \\
\hline Q3 house prices & 31,126 & 0.3618 & 0.481 & 0 & 1 \\
\hline $\begin{array}{l}\text { Q4 house prices } \\
\text { Net rent } £ 000^{\circ}\end{array}$ & $\begin{array}{l}31,126 \\
31,126\end{array}$ & $\begin{array}{l}0.4502 \\
0.8031\end{array}$ & $\begin{array}{l}0.498 \\
2.192\end{array}$ & $\begin{array}{l}0 \\
0\end{array}$ & $\begin{array}{l}1 \\
43.40\end{array}$ \\
\hline \multicolumn{6}{|l|}{ Variables of interest } \\
\hline Liked neighbourhood & 31,126 & 0.8924 & 0.310 & 0 & 1 \\
\hline Interact with neighbours (med), ref=low & 31,126 & 0.1671 & 0.373 & 0 & 1 \\
\hline Interact with neighbours (high) & 31,126 & 0.6782 & 0.467 & 0 & 1 \\
\hline Active in any local organisation & 31,126 & 0.3547 & 0.478 & 0 & 1 \\
\hline Contact with parent $(\mathrm{med})^{*}, \mathrm{ref}=\mathrm{low}$ & 31,126 & 0.2393 & 0.427 & 0 & 1 \\
\hline Contact with parent (high)* & 31,126 & 0.2505 & 0.433 & 0 & 1 \\
\hline Perceived job security (med), ref=low & 31,126 & 0.0913 & 0.288 & 0 & 1 \\
\hline Perceived job security (high) & 31,126 & 0.5903 & 0.492 & 0 & 1 \\
\hline New job & 31,126 & 0.0831 & 0.276 & 0 & 1 \\
\hline
\end{tabular}

Notes: $\mathrm{PR}=$ Private Renting; $\mathrm{PH}=$ Parental Housing; $\mathrm{HO}=$ Home Ownership; ${ }^{\mathrm{c}}=$ continuous rather than discrete measure.

Appendix A: Summary statistics of variables in use 


\section{Model 1}

$\mathrm{PR}$ to $\mathrm{HO}$ transition

(without interactions)

\section{Established Variables}

Wage rate t-1 $_{1}$

Wage rate $\mathrm{sq}_{t-1}$

Age 25-29, ref=18-24

Age 30-34

1-2 children in household $t-1$, ref $=$ no child

$3+$ children in household $t-1$

New birth $t-1$

Spouse present in household ${ }_{t-1}$

Q2 house prices ${ }_{t-1}, r e f=Q 1$

Q3 house prices ${ }_{t-1}$

Q4 house prices $t-1$

Net rent $£ 000_{t-1}$

Log-likelihood

LR $\operatorname{chi}^{2}(32)$

Prob $>\mathrm{chi}^{2}$

Observations used or switched to $\mathrm{HO}$

Number of respondents

${ }^{* * *} p<0.01,{ }^{* *} p<0.05,{ }^{*} p<0.1$

odds ratio

$-532.667$

559.13

0.000

3,074

410

\section{Model 2}

$\mathrm{PH}$ to $\mathrm{HO}$ transition (without interactions)

Notes: PR=Private Renting; $\mathrm{PH}=$ Parental Housing; $\mathrm{HO}=$ Home Ownership; $t-1$ = lagged by a year

Appendix B: Results from established drivers of tenure transition

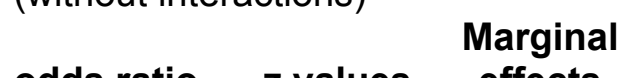

z values

effects

odds ratio $z$ values $\begin{gathered}\text { Marginal } \\ \text { effects }\end{gathered}$

\begin{tabular}{lrrrrr}
$1.005^{* *}$ & 2.43 & 0.001 & $1.004^{* * *}$ & 2.76 & 0.0003 \\
1.000 & -1.52 & 0.001 & 1.000 & -0.75 & 0.001 \\
$2.542^{* * *}$ & 3.88 & 0.135 & 1.117 & 0.59 & 0.019 \\
$2.878^{* *}$ & 2.56 & 0.153 & 0.995 & -0.02 & -0.001 \\
$0.548^{* *}$ & -2.11 & -0.090 & $0.496^{* * *}$ & -3.88 & -0.122 \\
$0.159^{* * *}$ & -2.72 & -0.305 & 0.499 & -1.33 & -0.121 \\
0.614 & -1.54 & -0.070 & 1.112 & 0.53 & 0.019 \\
$2.902^{* * *}$ & 4.72 & 0.154 & $6.175^{* * *}$ & 10.9 & 0.319 \\
0.871 & -0.57 & -0.020 & $0.519 * * *$ & -3.51 & -0.115 \\
0.832 & -0.59 & -0.027 & 0.754 & -1.19 & -0.049 \\
0.835 & -0.44 & -0.026 & 0.645 & -1.34 & -0.077 \\
$1.543^{* * *}$ & 14.49 & 0.063 & 0.978 & -0.70 & -0.004 \\
\hline
\end{tabular}

$-917.959$

319.89

0.000

4,052

536

effects

0003

.001

.122

.121

0.115

049 